Łukasz Stankiewicz

Uniwersytet Gdański

\title{
Pozycja studentów na uniwersytecie przyszłości - analiza wybranych dokumentów z debaty nad reformą szkolnictwa wyższego
}

Zmiany uniwersytetu polskiego po 1989 roku były wypadkową potrójnej presji - z jednej strony chęci liberalizacji pozbawionego autonomii systemu skonstruowanego w Polskiej Rzeczypospolitej Ludowej; z drugiej konieczności podporządkowania się procesom uniformizacji systemów akademickich dokonywanym $\mathrm{w}$ ramach organizacji ponad- i międzynarodowych (w Europejskim Obszarze Szkolnictwa Wyższego i Unii Europejskiej); z trzeciej korekt wynikających z funkcjonowania polskich szkół wyższych w warunkach postkomunistycznego „zwijania” państwa opiekuńczego, połączonego z wysokim prywatnym popytem na edukację akademicką. W ostatnich latach do wymienionych powyżej źródeł presji dołączyło czwarte, związane z postrzeganiem edukacji wyższej jako systemu, od którego zależny jest rozwój gospodarczy państwa i jako potencjalnie zglobalizowanej gałęzi przemysłu usługowego.

W trwającym od kilku lat procesie formułowania wprowadzanej obecnie reformy systemu szkolnictwa wyższego (SW) rolę odegrały wszystkie z wymienionych powyżej czynników. Procesowi przygotowywania reformy towarzyszyła szeroka debata publiczna, pozwalająca zróżnicowanym aktorom społecznym na ekspresję swoich interesów i przekonań dotyczących reformy i pożądanego kształtu systemu SW. W debacie wzięli udział potężni aktorzy, tacy jak państwo, wynajęci przez ministerstwo eksperci, akademickie organizacje branżowe, a także szereg aktorów o mniejszym znaczeniu - „zwykli” akademicy, studenci, administracja akademicka, przedsiębiorcy i inni interesariusze społeczni.

Jedną z osi debaty był stosunek pomiędzy umasowieniem edukacji wyższej, które dokonało się w Polsce w przeciągu ostatnich dwudziestu lat, a potrzebami państwa, gospodarki i kwestią jakości nauczania. „Problem” umasowienia SW, tak samo w Polsce, jak i innych krajach, które we wcześniejszych dekadach przechodziły ten proces, wiąże się ze zderzeniem interesów studentów (lub potencjalnych studentów) z interesami państwa (niebędącego $\mathrm{w}$ stanie finansować powszechnej edukacji trzeciego stopnia) i akademików (chroniących autonomię 
swoich instytucji). W ramach polskiej debaty dominujący głos należał do potężnych instytucji i organizacji, a przedstawiciele studentów nie odegrali w niej większej roli. Celem niniejszego artykułu jest analiza, na podstawie dwóch dokumentów, które odegrały istotną rolę $\mathrm{w}$ debacie, sposobu, na jaki dominujący aktorzy państwo i akademicy konceptualizowali przyszłą pozycję studentów, aktora obdarzonego znacznie mniejszą zdolnością do publicznej artykulacji swoich interesów.

\section{Kontekst badania}

Reformy polskiego SW po 1989 roku wiązały się z przywróceniem wolności akademickiej, zwiększeniem autonomii uniwersytetów, umożliwieniem tworzenia niepublicznych szkół wyższych i pobierania przez szkoły publiczne czesnego za usługi edukacyjne, o ile nie jest nim objęta więcej niż połowa studentów. Zmianom tym towarzyszyło znaczące ograniczenie stosunku wydatków publicznych na edukację wyższą i naukę wobec całości Produktu Krajowego Brutto (PKB) ${ }^{1}$, co w połączeniu z opisaną wyżej liberalizacją doprowadziło do powstania szerokiego rynku edukacji trzeciego stopnia. Rynek ten umożliwił dopływ prywatnych środków do publicznych i niepublicznych uniwersytetów, wymuszając jednocześnie zwiększenie produktywności kadry akademickiej (liczba studentów wzrosła w latach 1989 - 2010 pięciokrotnie ${ }^{2}$ przy nieznacznej zmianie liczby nauczycieli akademickich ${ }^{3}$ ). Tak samo jak w wypadku innych porównywalnych epizodów nagłego umasowienia edukacji wyższej spowodowało to obawy o pogorszenie się jakości nauczania. Ponieważ proces tworzenia nowych kierunków był całkowicie poddany mechanizmom rynkowym - to znaczy był zależny od kosztu prowadzenia zajęć danego rodzaju i popytu na nie, dodatkowym źródłem negatywnej oceny systemu stała się struktura nauczania, w której dominują kierunki z zakresu humanistyki, nauk społecznych, zarządzania i prawa. Struktura nauczania opierająca się na dominacji studentów z tych kierunków jest oceniana jako nieadekwatna wobec dominujących modeli teoretycznych przedstawiających funkcjonowanie gospodarek rozwiniętych i potrzeb polskiego rynku pracy. Innym ele-

\footnotetext{
1 M. Kwiek, Finansowanie szkolnictwa wyższego w Polsce a transformacje finansowania publicznego szkolnictwa wyższego w Europie, Center of Public Policy Studies „Research Papers” 2010, vol. 16.

2 World Bank, Tertiary Education in Poland, Biuro Banku Światowego w Polsce, Warszawa 2004, s. 2; Eurostat, Students in Tertiary Education, uzyskane 10 września 2012 z: http://epp.eurostat.ec.europa.eu/tgm/table.do?tab $=$ table\&init $=1 \&$ language $=$ en\&pcode $=$ tps $00062 \&$ plugin $=$.

3 Według zazwyczaj podawanych informacji liczba etatów nauczycieli akademickich w Polsce wzrosła z poziomu około 64 tys. w roku 1989 do 103 tys. w roku 2010 (wzrost o 61\%) i utrzymuje się na tym poziomie (GUS, Rocznik statystyczny 2011, Zakład Wydawnictw Statystycznych, Warszawa 2012, s. 343). Jednocześnie istnieją źródła sugerujące, że po wzięciu pod uwagę wielozatrudnienia rzeczywista liczba nauczycieli akademickich w tym okresie spadła o 10\% (M. Papuzińskia, J. Cieśla, Szkoły wyższereforma i mity, uzyskane 10 września 2012 z: http://www.polityka.pl/spoleczenstwo/artykuly/1513512, 1,szkoly-wyzsze--reforma-i-mity.read.).
} 
mentem systemu, który został poddany negatywnej ocenie, są osiągnięcia naukowe - uznane za nieadekwatne wobec potencjału państwa, a także słaba współpraca z przemysłem i komercjalizacja wiedzy co, jak w wypadku struktury nauczania, jest oceniane negatywnie ze względu na dominujące teoretyczne modele gospodarki, nawet pomimo relatywnie niskiej wiedzochłonności polskiego przemysłu 4 i relatywnie wysokiego (wśród krajów OECD) procentu badań kontraktowanych i finansowanych przez firmy prywatne i publiczne ${ }^{5}$.

Wymienione powyżej oceny zostały sformułowane w trakcie debaty publicznej ${ }^{6}$ towarzyszącej procesowi formułowania treści reformy szkolnictwa wyższego. Intencja przeprowadzenia reformy została zakomunikowana przez MNiSW przy nowo powstałym rządzie Platformy Obywatelskiej w 2007 roku. W debacie wokół wczesnych projektów reformy brało udział samo Ministerstwo Nauki i Szkolnictwa Wyższego (MNiSW), media, organizacje branżowe (reprezentujące rektorów szkół wyższych i studentów), pozarządowe i w pewnej formie - komercyjne. Istotne znaczenie dla debaty miały również wcześniejsze raporty organizacji międzynarodowych dotyczące SW w Polsce - szczególnie raport OECD z 2007 roku7, plany strategii rozwoju kraju i szkolnictwa wyższego formułowane w latach poprzednich ${ }^{8}$, a także dokumenty, takie jak Autodiagnoza polskiego środowiska naukowego ${ }^{9}$, będąca raportem $\mathrm{z}$ badań przeprowadzonych przez naukowców z Collegium Civitas.

Jednymi z najistotniejszych dokumentów, które powstały w trakcie debaty, były dwie kompletne strategie rozwoju szkolnictwa wyższego i reformy istniejącego systemu. Pierwsza z nich została przygotowana przez Instytut Badań nad Gospodarką Rynkową (IBnGR) i Ernst\&Young Business Advisory (E\&Y) ${ }^{10}$ zwycięzców w przetargu na przygotowanie strategii zorganizowanego przez MNiSW. Druga przez Konferencję Rektorów Akademickich Szkół Polskich

4 OECD, OECD Science, Technology and Industry Outlook 2008, uzyskane 10 września 2012 z: http://dx.doi.org/10.1787/453711056038.

5 OECD, OECD Reviews of Tertiary Education Poland, OECD Publishing 2007, s. 149.

6 Streszczone tutaj oceny stanu SW można znaleźć w wielu wypowiedziach medialnych, a także w raportach i strategiach dotyczących stanu SW w Polsce, np: Ernst \& Young Business Advisory \& Instytut Badań nad Gospodarką Rynkową, Diagnoza stanu szkolnictwa wyższego w Polsce, Instytut Badań nad Gospodarką Rynkową, Warszawa 2009; Konferencja Rektorów Akademickich Szkół Polskich, Strategia rozwoju szkolnictwa wyższego 2010-2020 - projekt środowiskowy, Wydawnictwo Uniwersytetu Warszawskiego, Warszawa 2009.

OECD, OECD Reviews of Tertiary...

8 Ministerstwo Nauki i Szkolnictwa Wyższego, Strategia rozwoju nauki w Polsce do 2015 roku, Warszawa 2007; Zespół doradców strategicznych Prezesa Rady Ministrów, Raport o kapitale intelektualnym Polski, Warszawa 2008; Ministerstwo Rozwoju Regionalnego, Narodowe strategiczne ramy odniesienia 2007-2013, Warszawa 2006; Ministerstwo Rozwoju Regionalnego, Program operacyjny kapitat ludzki, Warszawa 2006; Ministerstwo Nauki i Szkolnictwa Wyższego, Wyniki narodowego programu Foresight. Polska 2020, Warszawa 2009.

9 Autodiagnoza polskiego środowiska naukowego, Collegium Civitas, Warszawa 2007.

10 Ernst \& Young Business Advisory \& Instytut Badań nad Gospodarką Rynkową, Strategia rozwoju szkolnictwa wyższego w Polsce do 2020 roku, Instytut Badań nad Gospodarką Rynkową, Warszawa 2009. 
$(\text { KRASP })^{11}$, akademicką organizację branżową. Dokumenty te przedstawiają pozycję dwóch najbardziej znaczących aktorów debaty - z jednej strony państwa reprezentowanego przez posługujące się wiedzą ekspercką i w założeniu neutralne wobec toczącego się wokół reformy sporu organizacje pozarządowe (IBnGR) i komercyjne (E\&Y), z drugiej - przedstawicieli władz akademickich. Obie strategie zawierają kompleksową ocenę stanu SW w Polsce i proponują zmiany w sposobie jego finansowania i zarządzania.

W swoim badaniu skoncentrowałem się na tych dwóch dokumentach strategicznych, ponieważ w najpełniejszy sposób wyrażają one punkt widzenia dwóch głównych aktorów debaty, a wizje przedstawiane w ich ramach są kompleksowe i spójne. Oba dokumenty prezentują całościowy obraz SW i powiązań pomiędzy aktorami funkcjonującymi w ramach tego pola organizacji, zarówno w jego stanie obecnym, jak i docelowym. Moim głównym punktem zainteresowania były różnice i podobieństwa widoczne w sposobie konceptualizacji pozycji studentów aktora, który nie koncentrował na sobie uwagi medialnej, ani nie doprowadził do publikacji dokumentu o podobnej wadze jak dwie główne strony sporu.

\section{Teoretyczne podstawy badania}

Debatę dotyczącą szkolnictwa wyższego traktuję jako mający miejsce w przestrzeni publicznej spór dotyczący jej przyszłego kształtu. Aktorzy sporu posługują się dyskursywnymi modelami po to, by zdefiniować zarówno stan obecny jak i przyszły pola, które jest przedmiotem ich zainteresowania. Modele te definiuję za Fairclough'em jako imaginaria, czyli dyskursywne konstrukty mające na celu: „projekcję możliwych stanów rzeczy, możliwych światów (...), możliwych praktyk społecznych i ich sieci, ustalenie możliwych przyszłych form aktywności, podmiotów, relacji społecznych, instrumentów, obiektów, wartości, form świadomości"12. Jak pisze Bob Jessop ${ }^{13}$, opisując spory pomiędzy siłami społecznymi dotyczące kształtu ich instytucjonalnego otoczenia w warunkach kryzysu instytucji: „To, które rozwiązanie zostanie wybrane, jest częściowo zapośredniczone przez dyskursywne spory co do natury i znaczenia kryzysu i tego, co może po nim nastąpić. W okresach społecznej restrukturyzacji ściera się ze sobą wiele zróżnicowanych ekonomicznych, politycznych i społeczno-kulturowych narracji, które starają się nadać znaczenie zaistniałym problemom przez interpretację ich w kategoriach przeszłych zaniechań i nadchodzących szans. Zróżnicowane, prywatne i publiczne siły społeczne proponują nowe wizje, projekty i programy"14.

\footnotetext{
11 Konferencja Rektorów Akademickich Szkół Polskich, Strategia rozwoju szkolnictwa wyższego 2010-2020..

12 N. Fairclough, The Dialectics of Discourse, „Textus” 2001, 14(2), s. 233.

13 B. Jessop, The Future of Capitalist State, Polity Press, Cambridge 2002.

14 Ibidem, s. 92.
} 
To spotkanie idei nie dokonuje się bez konfliktu: „Istnieje przestrzeń dla konkurencji pomiędzy siłami społecznymi, dotyczącej strategii akumulacji, projektów państwowych i hegemonicznych wizji (...). Kluczową rolę odgrywa w niej rywalizacja indywidualnych i kolektywnych sił (...) artykułujących strategie, projekty i wizje mające załagodzić sprzeczności i konflikty i rozwiązać dylematy dotyczące rozmaitych obszarów i skal działania" (Gramsci 1971; Jessop 1990; Portelli 1973). Głównymi siłami zaangażowanymi w tę rywalizację są grupy interesu, partie polityczne i ruchy społeczne, przy czym to media masowe raczej niż sfera publiczna posiadają centralną pozycję pozwalającą na zapośredniczenie sporu dotyczącego hegemonii"15. Teoria Jessopa (który podobnie jak Fairclough posługuje się pojęciem imaginariów) odnosi się głównie do sporów pozwalających na konstytuowanie się, w momencie kryzysu, kolejnych reżimów gospodarczych. W perspektywie tego badania wykorzystuję ją jako model sporu o węższym zakresie. Należy przy tym pamiętać, że współczesne spory dotyczące SW nie dotyczą jedynie „oświaty”, ale dzięki popularnym teoriom dotyczącym powiązań pomiędzy systemem SW a gospodarką i aparatem państwowym, są przez samych zaangażowanych w nie aktorów rozumiane jako spory o przyszłą ekonomiczną i polityczną pozycję całego państwa.

Z tego, co napisane powyżej, wynika, że spory dotyczące kształtu pewnych instytucji mają miejsce (a) w przestrzeni publicznej czy medialnej, (b) uczestniczą w nich aktorzy kierujący się interesem własnym (c) i wykorzystujący jako narzędzia sporu pewne zasoby dyskursywne (imaginaria), które są (d) spójnymi, abstrakcyjnymi, zawierającymi informację o podmiotach i ich stosunkach modelami sytuacji. Celem aktorów jest przedstawienie takich imaginariów, łączących podmioty należące do będącego przedmiotem sporu pola, które rozwiązałyby "sprzeczności” i „dylematy”, jakie w danym momencie temu polu zagrażają. Ponieważ całość dowolnego pola ludzkiej działalności jest zbyt skomplikowana, by być przedmiotem całościowego zrozumienia czy namysłu, opisujące ją imaginaria są selektywne i niepełne. Jednym z głównych celów ich formułowania jest ustalenie, czy możliwe jest „unieruchomienie” (fixing) pewnych elementów jako możliwych przedmiotów ingerencji czy panowania ${ }^{16}$. Formułowane przez aktorów sporu „teorie” opisujące dane pole działania służą więc jednocześnie wytworzeniu wiedzy na temat przedmiotu sporu, jak i zdobyciu kontroli przez określenie tego w danym polu, co może być jej przedmiotem. Implementacja imaginarium konstytuuje składające się na nie podmioty, nawet jeśli wcześniej nie istniały one w polu. W ten sposób wiedza, a przynajmniej wiedza dotycząca stosunków społecznych, zarówno dotyczy pewnej sfery, jak i przyczynia się do jej ukonstytuowania.

\footnotetext{
15 Ibidem, s. 50.

16 Ibidem, s. 120; patrz też M. Foucault, Nadzorować i karać, tłum. T. Komendant, Aletheia, Warszawa 1998, s. 158-165.
} 
Imaginaria nie są tworzone w próżni, lecz w kulturowym kontekście, powodującym, że pewne rozwiązania są preferowane wobec innych. Wpływ tego kontekstu na lokalne rozwiązania i wyobrażenia dotyczące działania poszczególnych pól społecznych jest przedmiotem teorii dyskursu ${ }^{17}$, a także instytucjonalnej teorii

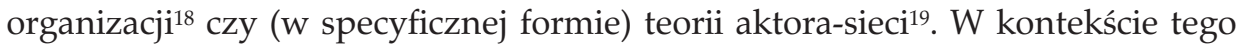
badania dokładne zdefiniowanie sposobu, na jaki dokonuje się transfer, czy sposobu, w jaki na lokalne praktyki wpływają Dyskursy przez duże ' $\mathrm{D}^{\prime 20}$, logiki instytucjonalne ${ }^{21}$, racjonalne mity ${ }^{22}$, czy ukryte w czarnych skrzynkach (blackboxed) zestawy praktyk ${ }^{23}$ - nie jest konieczne. Nie oznacza to, że sam transfer czy wpływ nie ma miejsca - istnieje pewien kanon dyskursów/mitów/modeli/teorii, poza który aktorzy debaty nie wychodzą i w ramach którego konstruują własne imaginaria pola. By uniknąć niejasności, w dalszej części tej pracy te zewnętrzne elementy teoretyczne, na których bazują lokalne imaginaria, będą nazywane, za instytucjonalną teorią organizacji, racjonalnymi mitami. Z perspektywy tego artykułu istotniejsze od wpływu rozprzestrzeniających się globalnie racjonalnych mitów jest to, że analizowane dokumenty są produkowane przez aktorów będących przedstawicielami pewnych grup interesu. Działania takich grup mają na celu zabezpieczenie własnej pozycji, zdefiniowanie przyszłości pola tak, by dani aktorzy zachowali swój instytucjonalny „stan posiadania”. Racjonalne mity (mające często zasięg globalny) są w tym celu reinterpretowane, lokalizowane i modyfikowane tak, by znalazło się w nich miejsce na podmioty, praktyki i sposoby działania, które dokonujący reinterpretacji aktorzy uznają za zgodne ze swoim interesem. Dyskursywny spór rozgrywa się na poziomie tych procesów redefinicji - poszczególni aktorzy definiują „własne” pozycje (to znaczy te, które w ich rozumieniu będą zajmować w systemie, który zaistnieje) jako dominujące, racjonalne i podmiotowe, tym samym redefiniując pozycje innych aktorów, z którymi będą, zgodnie $\mathrm{z}$ imaginarium, wchodzić $\mathrm{w}$ interakcje, jako podporządkowane i muszące podlegać stałemu nadzorowi pozycje przedmiotowe. Ponieważ imaginaria są spójnymi mapami praktyk, pozycji podmiotowych etc., więc nie ma w nich miejsca, jak w mniej sformalizowanych formach narracji, na czysto utopijne „pogodzenie sprzeczności" zachowujące interesy wszystkich stron. Aktorzy skrupulatnie projektując przyszły system instytucjonalny, definiują również pozycje władzy

\footnotetext{
17 N. Fairclough, Language and Power, Longman, London, New York 1989; M. Foucault, Archeologia wiedzy, tłum. A. Siemek, Aletheia, Warszawa 2002.

18 R.R. Friedland, R. Alford, Bringing Society Back in: Symbols, Practices, and Institutional Contradictions, [w:] The New Institutionalism in Organizational Analysis, pod red. W. Powell, P. DiMaggio, University of Chicago Press, Chicago 1991, s. 232; J. W. Meyer, B. Rowan, Institutionalized Organizations: Formal Structure as Myth and Ceremony, "American Journal of Sociology" 1977, s. 340.

19 B. Latour, Splatając na nowo to co społeczne, tłum. K. Abriszewski, A. Derra, Universitas, Kraków 2010.

20 J.P. Gee, An introduction to Discourse Analysis Theory and Method, Routledge, London, New York 1999.

21 R. Friedland, R. Alford. Bringing society...

22 J.W. Meyer, B. Rowan, Institutionalized Organizations...

23 B. Latour, Pandora's Hope: Essays on the Reality of Science Studies, Harvard University Press, Cambridge 1999 .
} 
(pozycje podmiotowe) i pozycje podporządkowane (przedmiotowe), zawsze starając się, by miejsca zajmowane przez nich samych, lub ich klientów, należały do pierwszej z tych kategorii.

Celem niniejszego badania jest porównanie skonstruowanych $\mathrm{w}$ dwóch dokumentach stworzonych na potrzeby debaty dotyczącej systemu szkolnictwa wyższego imaginariów tego systemu. Głównym przedmiotem zainteresowania są studenci, którzy, podobnie jak niektóre inne grupy funkcjonujące $\mathrm{w}$ ramach SW, posiadają niejasny (w porównaniu ze „standardowym" aktorem „standardowej” organizacji) status - znajdują się oni jednocześnie poza organizacją (jako jej klienci), i należą do niej (np. jako "uczniowie" przygotowywani przez "mistrzów” do dzieła jej reprodukcji). Ustalenie tego, czym są wobec uniwersytetu (produktem, klientem, uczniem wobec akademickich mistrzów, członkami społeczności etc.), jest konieczne dla każdego spójnego imaginarium uniwersytetu. Ich niejasny status jest wyjątkowo podatny na reinterpretacje i "unieruchomienie" (fixing) w ramach narracji debaty, w której ze względu na swój niski status społeczny i brak dostępu do zinstytucjonalizowanych narzędzi wyrażania swojej opinii biorą oni bardzo ograniczony udział. Zajmują więc oni pozycję, która musi być zdefiniowana, ale sami nie mają wielkiego wpływu na proces definiowania.

Materiał do badania (dwa dokumenty strategiczne) podległ kodowaniu ze względu na dwa elementy - rodzaje aktorów wymienianych w dokumentach i składających się na wewnętrzny i zewnętrzny „ekosystem” SW, i projektowane przez autorów dokumentów pożądane stosunki pomiędzy tymi aktorami. Umożliwiło to ustalenie, które z pozycji mają być pozycjami władzy, które mają być podporządkowane, i to, jakie są przyczyny i jakie mają być mechanizmy tego podporządkowania.

\section{Wyniki}

Modele przedstawione w obu strategiach można uznać za częściowo antagonistyczne. Po publikacji ich autorzy prowadzili krótkotrwały spór na łamach prasy ${ }^{24}$. Jednocześnie $\mathrm{w}$ obu wypadkach nie mamy do czynienia ze znaczącymi różnicami, jeśli chodzi o racjonalne mity, które są wykorzystywane do tworzenia narracji dotyczącej uniwersytetu. Zarówno w wypadku strategii E\&Y/IBnGR, jak i KRASP najważniejszymi punktami odniesienia są: koncepcje Gospodarki Opartej na Wiedzy Uczącego się społeczeństwa25, Nowe Zarządzanie Publiczne26, a także analogiczne dokumenty (raport OECD) i modele systemu akademickiego

\footnotetext{
24 P. Węgleński, Magister brojler, „Polityka”, 16 marca 2010, uzyskane z: http://www.polityka.pl/ kraj/analizy/1504212,1,jaka-strategia-dla-szkol-wyzszych.read.; B. Wyżnikiewicz, Zerwany pakt o nieagresji, „Polityka”, 24 marca 2010, uzyskane z: http://www.polityka.pl/kraj/analizy/1504428,1,zerwany-pakt-o-nieagresji.read.

25 B. A. Lundvall, The University in the Learning Economy, Aalborg Universitet, Aalborg 2002.

26 J.E. Lane, New Public Management, Routledge, London, New York 2000.
} 
(model amerykański). Żadna ze strategii nie powołuje się np. na tradycję Humboldtowską, autoteliczną wartość wiedzy etc. - do niedawna podstawowe składniki imaginariów uniwersytetu w kontynentalnej Europie.

Mimo zbieżności ",języków”, jakimi posługują się aktorzy, obie strategie znacznie różnią się proponowanymi rozwiązaniami kwestii finansowania i zarządzania szkołami wyższymi. Strony sporu dokonują odmiennej reinterpretacji wymienionych powyżej racjonalnych mitów, konstruując własne wersje imaginariów SW, zgodnie z którymi to aktorzy społeczni reprezentowani przez autorów danego dokumentu powinni sprawować podmiotową kontrolę nad podstawowymi instytucjami SW, ograniczając tym samym podmiotowość swoich przeciwników w debacie ${ }^{27}$.

Kwestia statusu studentów nie stanowiła centrum debaty, była jednak silnie wpleciona zarówno w narrację dotyczącą przyczyn „kryzysu” polskiego SW, jak i w proponowane tego kryzysu rozwiązania. Studenci, a raczej wywierany przez nich za pomocą rynku edukacyjnego wpływ, są w obu dokumentach pozycjonowani jako jedna z podstawowych przyczyn kryzysu. Obie strony prezentują odmienne, zbieżne z ogólną logiką ich wywodu koncepcje sposobu, na jaki wpływ studentów powinien zostać ograniczony tak, by osiągnąć pożądany kształt systemu SW.

\section{Studenci jako konsument i produkt}

Sposób, w jaki interpretowany jest statusu studenta, jest wyrażony wprost w strategii E\&Y/IBnGR:

(I) Czołowa rola uniwersytetów jako motoru postępu cywilizacyjnego i innowacji zaczęła być kwestionowana, choć z drugiej strony wyraźnie wzrosło zapotrzebowanie na ich najważniejszy produkt: wysoko kwalifikowaną siłę roboczą (E\&Y/IBnGR, s. 58).

Studenci nie są tutaj tratowani jako podmiot interakcji tworzących pole SW, ale raczej produkt tego pola. Taka reinterpretacja automatycznie zmienia status osób uczących się na uniwersytetach z podmiotowego - pozwalającego na współkształtowanie organizacji za pomocą rozmaitych narzędzi, na przedmiotowy pozwalający jedynie na bycie kształtowanym przez innych aktorów obecnych w polu.

27 Zarówno Nowe Zarządzanie Publiczne, jak i Gospodarka Oparta na Wiedzy są teoretycznymi konstrukcjami dobrze dopasowanymi do dostarczania dyskursywnej „amunicji” obu stronom konfliktu. Można je z łatwością reinterpretować albo na korzyść szerokiej autonomii uniwersytetów (czy dokładnie, ich managerów), albo precyzyjnej, choć dokonywanej za pomocą mechanizmów quasi-rynkowych, kontroli ze strony państwa. Obie strony korzystają również z rozbieżności pomiędzy deklarowanymi założeniami obu koncepcji a wyprowadzanymi z nich w różnych krajach zróżnicowanymi praktykami. 
Reinterpretacja ta dokonuje się przez zmianę sposobu rozumienia pożądanych powiązań pomiędzy poszczególnymi aktorami, którzy składają się (czy powinni się składać) na pole SW: uniwersytetów, państwa, rynku pracy i studentów. Uzasadnieniem dla niej jest negatywnie oceniana struktura kształcenia, blisko powiązana ze strukturą finansowania uniwersytetów.

Jedną z podstawowych zmian w strukturze finansowania proponowanych w strategii E\&Y/IBnGR jest zastąpienie dotacji stacjonarnej (przynależącej wszystkim uczelniom publicznym i wyliczanej na podstawie algorytmu) dotacją dydaktyczną przyznawaną w procesie konkursowym ogłaszanym przez ministerstwo. Konkurs (czy przetarg) miałby dotyczyć prowadzenia kierunków, które, zgodnie z analizami ekspertów, pozwolą na „dopasowanie struktury kształcenia na poziomie wyższym do potrzeb społecznych, w tym rynku pracy" (E\&Y/IBnGR, s. 85). Potencjalnym problemem związanym z takim (biurokratyczno-eksperckim) mechanizmem przyznawania dotacji jest:

(II) Niedostosowana do potrzeb gospodarki struktura kształcenia studentów ze względu na ekspercki (a nie rynkowy) sposób określania tej struktury (E\&Y/IBnGR, s. 85).

Ekspercki charakter prognoz dotyczących tego, jakie kierunki mają być zamawiane przez państwo:

(III) Pociąga za sobą możliwość popełnienia błędów, które nie występują w przypadku kontraktowania bazującego na rozwiązaniach rynkowych (E\&Y/IBnGR, s. 119).

W dalszej części strategii ryzyko to jest oceniane jako możliwe do przyjęcia, ze względu na to, że:

(IV) Funkcjonowanie rozwiązań rynkowych w obszarze szkolnictwa wyższego nie zawsze prowadzi do struktury kształcenia optymalnego z punktu widzenia rozwoju gospodarki. (...) Duża część niekorzystnych zjawisk w szkolnictwie wyższym koncentruje się w sektorze uczelni niepublicznych, które funkcjonują na zasadach zbliżonych do rynkowych (E\&Y/IBnGR, s. 120).

W powyższych fragmentach mamy do czynienia z obrazem sytuacji, w której państwo ma powoływać do istnienia kierunki kształcenia ze względu na interes „rynku pracy” czy gospodarki - rzeczywistych konsumentów uniwersyteckich wytworów. Rynkowy sposób ustalania, jakie kierunki mają powstać, jest jednocześnie przedstawiany jako rozwiązanie pozwalające potencjalnie uniknąć błędów w konstrukcji struktury kształcenia związanych z (postulowaną tu) scentralizowaną kontrolą biurokratyczną (fragment III) i jako źródło większości problemów, z którymi mamy do czynienia obecnie (według fragmentu IV). Pozorna sprzeczność obecna w tych twierdzeniach wynika $\mathrm{z}$ istnienia dwóch rozbieżnych interpretacji tego, czym są „rozwiązania rynkowe”. W pierwszym wypadku (fragment III) określenie to odnosi się do rynku, na którym konsumentami są pracodawcy a produktem studenci, w drugim (fragment IV) takiego, na którym konsumentem są studenci a produktem usługa edukacyjna. 
W ocenie E\&Y/IBnGR studencki konsumeryzm przyczynia się do patologizacji struktury nauczania w polskim SW. Aktorem, który może zaradzić tej sytuacji, jest państwo przyjmujące na siebie rolę pośrednika kształtującego akademię zgodnie z interesem prawdziwego klienta uniwersytetów (rynku pracy, gospodarki), nie pozwalając tym samym na wypaczenia struktury kształcenia, które powstają, gdy produkt (student) staje się klientem.

Na zbliżoną ocenę sytuacji natrafiamy w strategii KRASP. Podsumowując wyniki wspominanego wcześniej raportu OECD o sytuacji SW w Polsce, autorzy tej strategii piszą:

(V) O ofercie dydaktycznej szkół wyższych decydują warunki podażowe, przy bardzo słabej lub zerowej komunikacji z rynkiem pracy (KRASP, s. 48).

Natomiast w jednym z wcześniejszych fragmentów analizujących strukturę podaży i popytu na kształcenie, czytamy:

(VI) Rynek (...) poszukuje specjalistów z nauk technicznych, matematycznych i fizycznych, uczelnie zaś, zmieniając ofertę, w niewielkim stopniu uwzględniają te informacje, kierując się raczej oczekiwaniami maturzystów. Nie bez znaczenia jest także ich kondycja finansowa - selektywność oferty kierunkowej jest w dużym stopniu pochodną kosztów kształcenia (KRASP, s. 44).

W interpretacji KRASP niewłaściwa struktura nauczania wynika z popytu maturzystów, niedostatecznego finansowania przez państwo zmuszające uniwersytety do prowadzenia "tanich” kierunków i braku komunikacji z „rynkiem pracy”, co jest związane z jego „nieprzejrzystością” (KRASP, s. 44). Winny obecnym problemom jest więc „nadmiar” informacji płynących z rynku, na którym studenci są klientem, i niedobór informacji płynących z rynku, dla którego są oni produktem.

Rozbieżność między dwiema interpretacjami dotyczy głównie adekwatności lub nieadekwatności poziomu finansowania przez państwo - jest to element, który KRASP uznaje za jeden z kluczowych czynników negatywnie wpływających na Polskie SW zarówno w aspekcie jakości edukacji, jak i nauki. Zbieżności wyrażają się w podziale rynków na dwa rodzaje - nieracjonalne (bo wypaczające strukturę kształcenia) rynki, w których studenci kupują usługi edukacyjne, i racjonalny rynek pracy, z którego informacja powinna kształtować podaż kierunków uniwersyteckich.

Rozwiązania, które mają umożliwić poradzenie sobie z tą sytuacją, są w obu wypadkach odmienne. Biurokratyczno-ekspercki nadzór ministerstw proponowany przez E\&Y/IBnGR wiąże się z ustalaniem listy kierunków niejako ponad głową uniwersytetów, rynku pracy i rynku edukacyjnego; z kolei KRASP widzi sposób na zmianę struktury kształcenia w:

(VII) [Współdziałaniu] uczelni z pracodawcami oraz przedstawicielami organizacji i stowarzyszeń zawodowych, jak też instytucji życia publicznego, w ramach organów uczelni, podejmujących decyzje dotyczące procesu i programu studiów (KRASP, s. 73). 
(VIII) Misje poszczególnych szkół wyższych będą określane przez nie autonomicznie we współpracy $\mathrm{z}$ interesariuszami zewnętrznymi, ale zróżnicowane $\mathrm{w}$ celu dostosowywania działalności uczelni do jej własnej wizji rozwoju, w tym profilu naukowego i obszarów kształcenia oraz do potrzeb społecznych i preferencji kandydatów na studia (KRASP, s. 64).

W tym rozwiązaniu uczelnie są autonomicznymi aktorami, którzy w swoich decyzjach biorą pod uwagę zarówno informacje z rynku pracy, jak i konsumenckie preferencje studentów.

To ostatnie nie zmienia faktu, że celem obu aktorów jest przedstawienie takiej wizji struktury SW, w której inni aktorzy (uczelnie i studenci z punktu widzenia strategii przygotowanej dla MNiSW oraz państwo i studenci z punktu widzenia strategii KRASP) zostaną w jakimś stopniu pozbawieni podmiotowości. Celem autorów obu strategii jest takie zdefiniowanie sytuacji, by to oni (lub ich klient) byli interpretatorami sygnałów płynących z rynku pracy, który w obu wypadkach jest traktowany jako jedyne źródło społecznej racjonalności. Zarówno w pierwszej, jak i drugiej strategii wymaga to przedstawienia mechanizmu, za pomocą którego pozbawieni tej części swojej władzy, która płynęła z ich statusu konsumentów, studenci będą kształtowani zgodnie z potrzebami innych aktorów społecznych. W obu wypadkach jednym z głównych elementów wyobrażonej struktury przyszłego uniwersytetu mają być systemy służące kontroli, kierowaniu w odpowiednie ścieżki i wreszcie podziałowi na zróżnicowane kategorie „produktu”, który w obecnym systemie deformuje strukturę kształcenia za pomocą swoich konsumenckich wyborów.

\section{Fantazje kontroli}

Podstawową kwestią, z którą musieli zmierzyć się autorzy obu strategii, jest niemożliwość włączenia do ich imaginariów SW rynku i konkurencji jako elementów automatycznie rozwiązujących problem struktury kształcenia. Rozwiązania rynkowe były preferowane w czasie polskiej transformacji i rynkowy fundamentalizm ${ }^{28}$, znacznie słabszy w krajach zachodu od czasu wybuchu „wielkiej recesji” lat 2008-2012, nadal jest dominującą perspektywą ideologiczną w Polsce ${ }^{29}$. Ślady tego ideologicznego podejścia widać w strategii E\&Y/IbnGR, gdzie krytyka sposobu, w jaki rynki edukacyjne ukształtowały strukturę kształcenia (fragment III), występuje stronę po rytualnym (tzn. niemającym żadnego wpływu na dalszą część wywodu) potwierdzeniu wyższości rozwiązań rynkowych nad biurokratycznymi (fragment II). Zgodnie z teorią zależności od zasobów ${ }^{30}$ wpływ, jaki pod-

28 G. Soros, The Crisis of Global Capitalism: Open Society Endangered, Public Affairs, New York 1998; J.E. Stiglitz, Globalizacja, PWN, Warszawa 2004.

${ }_{29}$ T. Kowalik, www.polskatransformacja.pl, Warszawskie Wydawnictwo Literackie Muza SA, Warszawa 2009.

30 J. Pfeffer, G. Salancik, The External Control of Organizations: A Resource Dependence Perspective, Stanford Business Books, Stanford 2003. 
mioty z otoczenia organizacji mogą na nią wywierać, związany jest ze stopniem, $\mathrm{w}$ jakim przetrwanie danej organizacji zależy od zróżnicowanych zasobów uzyskiwanych dzięki kontaktom z tymi podmiotami. Struktura opisana zarówno w strategii KRASP jak i E\&Y/IBnGR wskazuje, że uniwersytety są zależne od państwa i płacących czesne studentów. Państwo nie wywiera na zależne od siebie organizacje należytego wpływu, ponieważ pieniądze na utrzymanie uniwersytetów są dzielone zgodnie z niemodyfikowanym w zależności od efektów pracy danej instytucji "algorytmem” lub przez przyznające granty niepolityczne ciała eksperckie. Z kolei studenci wywierają na uniwersytety znaczny wpływ za pomocą mechanizmów rynkowych. Jest to wpływ patologiczny, ponieważ zamiast kierować powstawaniem kierunków zgodnie z zapotrzebowaniem swoich prawdziwych "klientów" (przedsiębiorców) na swoje prawdziwe "produkty” (wykwalifikowaną siłę roboczą), uniwersytety muszą sprzedawać usługi edukacyjne nie zorientowanym $\mathrm{w}$ tym, co jest potrzebne polskiej gospodarce, maturzystom (fragmenty V, VI). Próba wyobrażenia sobie sposobu regulacji takiego systemu jest złożona, ponieważ uniwersytety nie są bezpośrednio zależne finansowo od przedsiębiorców, rynku pracy, gospodarki etc. - to znaczy, ich „prawdziwi” klienci nie mają na strukturę kształcenia żadnego wpływu. Obie strategie zawierają wstępne propozycje rozwiązania tego problemu opisane w poprzedniej części artykułu. Pierwsze $\mathrm{z}$ tych rozwiązań, obecne $\mathrm{w}$ strategii powstałej na zamówienie państwa, znacząco ograniczałoby wolność akademicką, redukując ją do „wolności" dobrego wykonywania zadań zlecanych przez podmioty zewnętrzne wobec akademii. Drugie rozwiązanie, proponowane przez akademickie władze, ograniczałoby z kolei wpływ państwa na uniwersytety - byłoby ono oddzielone od zarządu uniwersytetów siecią odpolitycznionych ciał eksperckich, a rola interpretatora potrzeb gospodarki zostałaby przejęta przez same szkoły wyższe. Ten spór o władzę i podmiotowość nie odnosi się jednak do studentów, ponieważ obie strategie zgadzają się na konieczność ograniczenia ich wpływu. W tym celu konstruowane są imaginaria systemów kontroli, w ramach których przesadna, nieracjonalna konsumencka wolność ustąiłiaby drobiazgowej kontroli dokonywanej zgodnie z potrzebami prawdziwych klientów SW.

\section{KRASP}

System kontroli w strategii KRASP zakłada interakcję pięciu aktorów - szkół wyższych, państwa, liceów, rynku pracy i gospodarki wiedzy. Państwo ma spełniać funkcję doradczą i informacyjną, jego celem ma być:

(IX) Zapewnienie (...) powszechnej dostępności informacji dotyczącej:

- aktualnego stanu rynku pracy, w tym różnic w zarobkach absolwentów poszczególnych (...) uczelni; 
- przewidywanych (w horyzoncie kilku lat) potrzeb rynku pracy i poziomu wynagrodzeń w różnych zawodach;

- przewidywanych długookresowych zmian na rynku pracy (...) oraz wspieranie zinstytucjonalizowanych form doradztwa i pomocy w zakresie planowania kariery zawodowej, adresowanych przede wszystkim do uczniów szkól średnich, ale także do studentów (KRASP, s. 74).

Działalność państwa ma się więc ograniczać do dostarczania informacji dotyczącej perspektywicznych z punktu widzenia studentów wyborów, co umożliwi im podjęcie „racjonalnej” decyzji na podstawie danych o zarobkach.

Rola uczelni jest szersza i ma obejmować interakcje z przyszłymi studentami na poziomie szkolnictwa I i II stopnia, a także współkształtowanie doświadczenia edukacyjnego w szkołach podstawowych i średnich:

(X) Upowszechnianie różnych form kształcenia „przedmaturalnego” (...), służących lepszemu przygotowaniu do podjęcia studiów i zwiększeniu motywacji do studiowania w obszarach nie cieszących się dostatecznym zainteresowaniem kandydatów, a istotnych z punktu widzenia realizacji celów społecznych, zwłaszcza rozwoju gospodarki opartej na wiedzy (KRASP, s. 74).

Kierowanie studentów na kierunki cieszące się mniejszym zainteresowaniem na rynku wiązałoby się również ze stosowaniem zachęt finansowych:

(XI) Stosowanie zachęt dla studentów do podejmowania studiów w obszarach ważnych ze względów społecznych i gospodarczych w postaci odpowiednich rozwiązań w systemie pomocy materialnej (KRASP, s. 74).

Kierowanie studentów na ścieżki edukacji „ważne ze względów społecznych i gospodarczych" jest równoznaczne ze wsparciem wzbudzających relatywnie niskie zainteresowanie na rynku edukacyjnym (i kosztowniejszych dla uczelni) kierunków z zakresu nauk przyrodniczych, inżynieryjnych i technicznych. Jest to działanie związane z wizją rozwijającej się gospodarki opartej na wiedzy - segmentu jednocześnie elitarnego i właściwie w Polsce nieistniejącego, do powstania którego uniwersytety miałyby się we współpracy z państwem i przemysłem przyczynić. Ta misja budowy nowej gospodarki różni się od działań, których celem ma być przygotowanie studentów do wymagającego innego zestawu umiejętności „realnie istniejącego" rynku pracy. W diagnozie istniejącej obecnie sytuacji czytamy:

(XII) Niektóre poszukiwane przez pracodawców umiejętności w ogóle nie były i ciągle w wystarczającym stopniu nie są przedmiotem zainteresowania wielu uczelni (...). Umiejętność uczenia się i chęć doskonalenia kwalifikacji są znaczącym argumentem przemawiającym za zatrudnieniem absolwenta, nawet jeśli jego wiedza kierunkowa, czy specjalizacyjna nie do końca pasuje do profilu firmy. Ważna jest również przedsiębiorczość, bo praca na własny rachunek (do której uczelnie powinny przygotować swoich absolwentów), to znaczna część rynku przyszłości (KRASP, s. 45).

Zapewnienie konwergencji pomiędzy umiejętnościami studentów a realnie istniejącym rynkiem pracy wymaga współpracy z tym ostatnim, przy czym, inaczej 
niż w strategii E\&Y/IbnGR, ma to być współpraca równych partnerów, a nie podporządkowanie akademii ekspertyzom państwa, które we własnym zakresie rozpoznaje potrzeby gospodarki.

Podziałowi gospodarki na dwie części - stanowiącą wspólny projekt państwa, uniwersytetów i przemysłu gospodarkę opartą na wiedzy i posiadający raczej ograniczone wymagania rynek pracy odpowiada podział edukacji na dwie ścieżki - masową i elitarną. Rozróżnienie to jest utożsamiane $\mathrm{z}$ wprowadzonym $\mathrm{w}$ ramach Procesu Bolońskiego podziałem na studia I i II stopnia. W strategii KRASP sugeruje się "miękkie” metody służące zróżnicowaniu tych poziomów w celu uczynienia magisterskiego poziomu studiów poziomem elitarnym:

(XIII) Podniesienie poziomu kształcenia na studiach II stopnia przez ograniczenie odsetka osób podejmujących studia II stopnia bezpośrednio po ukończeniu studiów I stopnia metodami administracyjnymi i przez "ostrą" selekcję kandydatów jest nierealne i nie byłoby właściwe. Konieczne jest więc podejście ewolucyjne, poprzez działania kształtujące wśród pracodawców właściwy obraz kompetencji osób kończących studia I stopnia (KRASP, s. 80).

Sytuacja, w której większość uczących się kończy studia magisterskie, jest oceniana jako patologiczna (z perspektywy założeń Procesu Bolońskiego), ale perswazyjne czy edukacyjne działania mają tutaj być skierowane nie tylko do studentów, lecz również do pracodawców. Studenci mają być motywowani do podejmowania niepopularnych studiów, a pracodawcy do obniżenia swoich wymagań co do wykształcenia pracowników.

Ogólny obraz strategii KRASP wskazuje na chęć zachowania autonomii przez uczelnie - interakcje z ich otoczeniem mają być dobrowolne, partnerskie i niezapośredniczone, a państwo ma spełniać jedynie rolę doradczą i koordynacyjną. Patologie wywołane przez rynki usług edukacyjnych mają być zmniejszone dzięki zastosowaniu "miękkich" metod perswazyjnych i edukacyjnych. Istotną rolę ma spełniać swego rodzaju „edukacja do edukacji”, gdzie ingerencja uczelni w proces nauczania zaczyna się już na poziomie szkół podstawowych, gimnazjów i liceów. Celem tych ingerencji jest pokierowanie przyszłymi studentami tak, by ich wybory zaspokajały wielkie kompleksy racjonalności społecznej - zarówno istniejące (rynek pracy), jak i mające powstać (gospodarkę opartą na wiedzy). Ostatecznym celem edukacji jest więc produkowanie funkcjonalnych elementów społeczeństwa, poprzedzone przez uświadomienie elementom, co oznacza być poprawnie funkcjonalnym. Oznacza to, że w perspektywie tej strategii zakłada się, że ogół ludności nie jest $\mathrm{w}$ stanie racjonalnie ocenić własnych potrzeb i że jedynymi źródłami racjonalności są: rynek (przedsiębiorcy), eksperci wypowiadający się o tym rynku, doświadczenie krajów wyżej rozwiniętych, zamknięte w imaginariach takich jak gospodarka oparta na wiedzy i działania podmiotów mających na celu realizację tych imaginariów (uczelni, firm, agend państwowych). Jednocześnie wprowadzenie "miękkich” systemów kontroli nie ma się wiązać z ograniczeniem, a raczej ze zwiększeniem autonomii szkół wyższych. Jednym z elementów, 
który nie został objęty tą ogólną wizją, jest kryterium dystynkcji pozwalające podzielić studentów na grupy mające stanowić produkt masowy i elitarny. To kryterium dystynkcji stanowi centrum fantazji kontroli w strategii E\&Y/IBnGR.

\section{E\&Y/IBnGR}

Podział studentów na kilka grup otrzymujących edukację o zróżnicowanej jakości jest jednym z podstawowych celów strategii E\&Y/IBnGR:

(XIV) Uczelnie muszą zapewniać kształcenie odpowiednie do podjęcia zróżnicowanych zadań: od rutynowej pracy umysłowej (tzw. „umysłowi robotnicy”), przez zadania szczególnie użyteczne społecznie (leczenie, kształcenie), po dokonywanie odkryć naukowych i tworzenie innowacji technologicznych (E\&Y/IBnGR, s. 46).

Najniższy poziom edukacji - multidyscyplinarne programy licencjackie mają być według opisywanej tu strategii odpowiednikiem amerykańskich koledży:

(XV) Programy multidyscyplinarne będą musiały zawierać przedmioty z różnych dziedzin wiedzy (wymaganie różnorodności) oraz kłaść nacisk na kształcenie umiejętności tranzytywnych niezbędnych przy wykonywaniu różnych zawodów (E\&Y/IBnGR, s. 48).

Ich celem ma być w opisywanym tu modelu szkolenie najniższej, niewyspecjalizowanej kategorii pracowników umysłowych przygotowanych do częstych zmian zatrudnienia. Są to umiejętności analogiczne do tych, których uczenie postuluje się w strategii KRASP jako reakcję na potrzeby "realnego" rynku pracy (fragmenty XII, XIII).

W uzasadnieniu dla wprowadzenia kursów multidyscyplinarnych (poza potrzebami rynku pracy) autorzy strategii podają również cele wychowawcze:

(XVI) Odroczenie wyboru specjalizacji, które pozwala studentom na ocenę swojego potencjału i wykorzystanie go w najlepszy sposób. Jak wskazują badania, wyboru kierunku dokonuje się przeważnie w oparciu o opinie innych osób (nauczycieli, kolegów, rodziców). Opóźnienie wyboru specjalizacji i zapewnienie szerokiej bazy wykształcenia ogólnego daje szanse na lepsze zrozumienie konsekwencji tego wyboru i uniezależnienie się od opinii środowiska, co jest szczególnie istotne ze względu na dążenie do wyrównywania szans edukacyjnych (E\&Y/IBnGR, s. 50).

(XVII) Samodzielne kształtowanie programu studiów, co uczy odpowiedzialności za własne decyzje edukacyjne i życiowe, pozwala rozwijać zainteresowania, a także kształci umiejętność uczenia się (E\&Y/IBnGR, s. 50).

Dzięki tym procesom wychowawczym studenci studiów masowych, przyszli robotnicy wiedzy, mają mieć lepszą szansę na ocenę własnych perspektyw na rynku pracy. Ta zakładana niezdolność uczniów studiów licencjackich do właściwej oceny własnych perspektyw (co ma swoje analogie w strategii KRASP, tam jednak wobec całej „populacji” studentów - patrz fragmenty VI, X, XI) może wynikać 
z zakładanego w strategii niskiego kapitału intelektualnego, społecznego i finansowego grupy, która ma stanowić ich podstawowych klientów. Jak czytamy w jednym z późniejszych fragmentów:

(XVIII) Nadanie studiom I stopnia i tytułowi licencjata odpowiedniego statusu jest kluczowe dla procesu wyrównywania szans edukacyjnych i efektywnego wykorzystania kapitału ludzkiego w gospodarce. $Z$ jednej strony, osoby pochodzące z grup o niższym statusie społecznym i ekonomicznym mogą uznawać perspektywę studiów dwustopniowych za zbyt długą (zwłaszcza gdy są to studia płatne). Z drugiej zaś, kompetencje zdobywane na I stopniu studiów są często wystarczające do podjęcia pracy w wielu zawodach bazujących na pracy umysłowej (E\&Y/IBnGR, s. 54).

Proces wychowawczy ma więc, w zamierzeniach E\&Y/IbnGR, pozwalać studentom z klas niższych na racjonalne rozpoznanie i wzięcie odpowiedzialności za własną, klasowo zdeterminowaną ścieżkę życiową.

W przeciwieństwie do licencjackich programów multidyscyplinarnych, możliwość rozpoczęcia nauki na ścieżkach II i III stopnia (studia magisterskie i doktoranckie) miałaby być ograniczona w celu zwiększenia wagi tych studiów:

(XIX) W Polsce udział studentów studiów II stopnia w całej populacji studentów jest wyraźnie wyższy niż w krajach OECD. Kształcenie I stopnia powinno więc być otwarte dla coraz większego odsetka absolwentów szkół średnich, a kształcenie II stopnia powinno stawać się dobrem dostępnym selektywnie i dla najlepszych (E\&Y/IBnGR, s. 54-5).

W przeciwieństwie do osób o niskim statusie materialnym i społecznym, których przeznaczeniem jest zajęcie pozycji robotników wiedzy, „najlepsi” studenci nie wymagają według strategii E\&Y/IBnGR dodatkowych procesów wychowawczych, pomimo że ich przeznaczeniem jest zajęcie bardziej uprzywilejowanych i odpowiedzialnych pozycji w hierarchii społecznej. Głównym celem procesów wychowawczych wydaje się więc być raczej ograniczenie niż rozbudzanie czy (jak w strategii KRASP) kierowanie ambicjami edukacyjnymi.

Strategia sugeruje, że powinna istnieć drożność pomiędzy poszczególnymi poziomami edukacji:

(XX) Absolwent dowolnego typu programu może ubiegać się o przyjęcie na dowolny program wyższego stopnia. (...) Przy przejściu z niższego na wyższy stopień studiów (...), uczelnia będzie mogła określić zakres kompetencji, których posiadanie przez kandydata będzie weryfikowane w drodze egzaminu. W celu zwiększenia drożności między poszczególnymi grupami programów dyplomowych, uczelnie będą mogły prowadzić odpłatne kursy wyrównawcze (por. 7.E) pozwalające kandydatom uzupełnić braki wiedzy i kompetencji wymaganych do podjęcia studiów na danym programie dyplomowym (E\&Y/IBnGR, s. 49).

"Drożność" pomiędzy stopniami edukacji wiąże się więc z wprowadzeniem podwójnej bariery - administracyjnej związanej z koniecznością zdania egzaminu i finansowej. W ten sposób, pomimo formalnego zachowania możliwości przechodzenia pomiędzy stopniami studiów, możliwość zdobycia „elitarnych” 
form edukacji przez osoby z niskim statusem społeczno-ekonomicznym jest w strategii E\&Y/IBnGR ograniczana w jeszcze większym zakresie.

W porównaniu do strategii KRASP, proponującej "miękkie" kształtowanie wyborów studentów na podstawie porozumienia elitarnych aktorów społecznych, strategia E\&Y/IBnGR zawiera szerszy zakres celów społecznych.

Po pierwsze zakłada ona, że właściwą formą upodmiotowienia studentów jest skłanianie ich do internalizacji ich pozycji klasowej. Jednym z celów przeznaczonego dla nich rodzaju szkół jest umożliwienie im dokonania „wolnego" wyboru tego, co w rozumieniu autorów strategii jest konieczne.

Po drugie widzi ona $w$ strukturze studiów trójstopniowych, wprowadzonej w ramach Procesu Bolońskiego, szansę na restytucję dystynktywnej funkcji edukacji, ograniczoną przez występujące wobec "nadmiernej” ilości studentów II stopnia i braku zróżnicowania szkół podług ich jakości zjawisko „inflacji dyplomów”31.

Po trzecie, specyficzną innowacją strategii E\&Y/IBnGR jest pojęcie „efektywności wykorzystania kapitału ludzkiego" (patrz frag. XVIII), oznaczające kierowanie osób z odpowiednio niższym lub wyższym wejściowym kapitałem ludzkim na mniej lub bardziej wymagające i prestiżowe ścieżki edukacyjne. Chociaż zabiegi tego rodzaju rzeczywiście są "efektywne” w tym sensie, że szkolenie osób z deficytem kapitału społecznego do prostych prac, a osób z grup uprzywilejowanych do prac bardziej wymagających wymaga mniejszych nakładów i „marnuje" mniej istniejącego już kapitału, cel ten, $\mathrm{w}$ formie, $\mathrm{w}$ jakiej został przedstawiony, można utożsamić z planową, sztywną reprodukcją istniejącej struktury klasowej społeczeństwa.

\section{Podsumowanie}

Ograniczenia powyższego badania wiążą się po pierwsze z definiowaniem studenckiej podmiotowości wyłącznie w kontekście roli studentów jako konsumentów usług edukacyjnych, po drugie ze statusem samych badanych dokumentów, będących wypowiedziami stron sporu politycznego, rozwiązanego ostatecznie na sposób, który nie zawdzięcza wiele żadnemu z analizowanych tu dokumentów. Uważam jednak, że wobec pozytywnych wyników liberalizacji polskiego SW dość jednoznacznie wrogie podejście wielu aktorów społecznych do podstawowego efektu tej liberalizacji - umasowienia edukacji wyższej, zasługuje na analizę, nawet jeśli jest to analiza intencji raczej niż dokonań. Jednocześnie nie istnieje material, który dawałby nam lepszy wgląd w intencje poszczególnych aktorów społecznych w odniesieniu do SW niż materiały wytworzone podczas debaty dotyczącej bieżącej reformy.

31 Jej klasyczny opis można znaleźć w P. Bourdieu, Homo Academicus, Stanford University Press, Stanford 1990. 
Obie analizowane wizje są wizjami konserwatywnymi. Wizja KRASP zakłada ochronę akademickiej autonomii przed studenckimi wyborami konsumenckimi, wizja E\&Y/IBnGR próbuje sformułować obraz społeczeństwa, którego struktura klasowa jest osłaniana przed nadmierną ambicją klas niższych i dewaluacją tradycyjnych źródeł racjonalizacji przewagi klas uprzywilejowanych. Podmiotowość rozumiana raczej jako podmiotowość konsumenta niż człowieka czy obywatela, by nie stanowiła zagrożenia dla cenionych przez autorów poszczególnych strategii instytucji społecznych, musi zostać, za pomocą skomplikowanej społecznej maszynerii, przekształcona w podmiotowość poddającą się kontroli. W wypadku strategii KRASP jest to podmiotowość funkcjonalnego elementu gospodarki rynkowej, instruowanego o tym, czego wymaga od niego racjonalność machiny społecznej i budującego swoją ścieżkę życiową w oparciu o to zrozumienie. W strategii E\&Y/IBnGR jest to podmiotowość klasowa, pozwalająca zrozumieć poszczególnym przedstawicielom wspólnoty, gdzie znajduje się przeznaczone dla nich miejsce w społecznej piramidzie, nawet jeśli zrozumienie to musi się dokonać wbrew nadmiernym ambicjom wzbudzonym w nich przez „nauczycieli, kolegów, rodziców". Tym, co w analizowanych tu strategiach jest elementem najbardziej paradoksalnym, jest połączenie ich hierarchicznego konserwatyzmu i strategii odgórnej kontroli opartej na porozumieniu elit z koncepcjami gospodarki opartej na wiedzy, zakładającymi upowszechnienie wiedzy, „kreatywną destrukcję"32 istniejących struktur gospodarczych, a także istnienie zaufania pomiędzy współpracującymi ze sobą grupami wytwórców wiedzy ${ }^{33}$. Chociaż wobec trwającego wciąż kryzysu można wątpić w słuszność jakichkolwiek teorii gospodarki, to jednocześnie trudno wyobrazić sobie model społeczny mniej przystosowany do potencjalnego rozkwitu gospodarki wiedzy niż społeczeństwo klasowe, żmudnie reprodukowane podług planów zarysowywanych przez elity, uznające ludową ambicję za zagrożenie dla kształtu swoich instytucji i dla legitymizacji swojej pozycji społecznej. Autorzy, dbając głównie o własne statyczne wizje społeczne, wydają się zapominać, że współczesne rynki wysokich technologii wzięły swój początek z deliberacji prowadzonych raczej w garażach niż na salonach.

\section{Summary}

The Status of Students at the University of the Future - an Analysis of the Main Documents of the Debate on Polish Higher Education Reform

The actors taking part in the public debate concerning the current higher education reform in Poland had diverse interests but they operated in a fairly homogenous field of ide-

32 J. Schumpeter, Kapitalizm, socjalizm, demokracja, PWN, Warszawa 1995, s. 99-105.

33 B. A. Lundvall, The Social Dimension of the Learning Economy, DRUID, Aalborg University, Aalborg 1996. 
ology/discourse. For the dominant actors such as the Polish state and the academic leadership the ideologies/discourses of Knowledge-Based Economy, New Public Management and market fundamentalism determined what could and could not be said. United in ideology, the dominant groups struggled for power - trying to define the future management and financial structures of higher education institutions (HEIs) in line with their interests.

This paper is based on an analysis of two strategic documents that had a large impact during the debate. The first document was produced by the Rectors Conference, the second one by Ernst\&Young Business Advisory and The Gdańsk Institute for Market Economics (on behalf of the Ministry of Science and Higher Education). The aim in researching those documents was to determine how the dominant actors conceptualized the future position of students - an actor that had a limited impact on the debate.

In both documents the students are defined as irrational social subjects, whose influence as consumers should be restricted for the good of the industry and the higher education institutions. The students' position is redefined from 'client' to 'product' of HEIs which allows for the positioning of "labor market" and "knowledge-based economy" as the real clients of the universities. Because of differentiated needs of the new clients, the product of HEIs is to be divided into two categories. First of them is the "mass product" that is destined for the currently existing labor market and is to be created by processing the lower-class human material. Second category is the "luxury product" that is destined for the prestigious professions and the not yet existent knowledge-based economy. 